Notes

\title{
CORRALLING CONSTITUTIONAL FACT: DE NOVO FACT REVIEW IN THE FEDERAL APPELLATE COURTS
}

\begin{abstract}
ADAM HOFFMAN
No two terms of legal science have rendered better service than "law" and "fact." They are basic assumptions; irreducible minimums and the most comprehensive maximums at the same instant. They readily accommodate themselves to any meaning we desire to give them.... What judge has not found refuge in them? The man who could succeed in defining them would be a public enemy. They may torture the souls of language mechanicians who insist that all words and phrases must have a fixed content, but they and their flexibility are essential to the science which has to do with the control of men through the power to pass judgment on their conduct.
\end{abstract}

Leon Green ${ }^{1}$

We acknowledge that there are more verbal formulas for the scope of appellate review ... than there are distinctions actually capable of being drawn in the practice of appellate review. But even if, as we have sometimes heretically suggested, there are operationally only two degrees of review, plenary (that is, no deference given to the tribunal being reviewed) and deferential, that distinction at least is a feasible, intelligible, and important one.

Richard Posner ${ }^{2}$

Copyright $@ 2001$ by Adam Hoffman.

1. JUDGE AND JURY 270-71 (1930).

2. United States v. Boyd, 55 F.3d 239, 242 (7th Cir. 1995) (citations omitted). 


\section{INTRODUCTION}

As a recent circuit split indicates, the scope of application of the federal doctrine of constitutional fact, under which fact determinations are subjected to plenary review, remains a contested if somewhat esoteric corner of the law. In Mahaffey $v$. Page, ${ }^{3}$ the Seventh Circuit Court of Appeals adopted a de novo standard of review for a trial court's determination of a prima facie showing of racial discrimination in the use of a peremptory strike. ${ }^{4}$ The Mahaffey court noted that although the ultimate determination of whether the striking counsel's intent was discrimination is an issue of fact to be reviewed deferentially, whether the facts alleged by the defendant make a prima facie case of discrimination is a mixed question of fact and law. ${ }^{5}$ Because the question was mixed, the allocation between the finder of fact and the reviewing court of the primary burden of answering it was not easily settled. The court decided on a de novo standard, thereby allocating that burden to itself, for two reasons. Most decisive, according to the decision, was the importance of the constitutional right at issue and the gravity of the threat to that right in the

3. 162 F.3d 481 (7th Cir. 1998).

4. Under Batson v. Kentucky, 476 U.S. 79, $96-98$ (1986), the burden is on the defendant to make a prima facie showing of racial discrimination. If such a showing is made, the burden shifts to the prosecutor, who must provide a race-neutral justification for the strike or strikes in question. The court then determines whether this justification is pretextual. Mahaffey, 162 F.3d at 482-83. Mahaffey was limited in United States v. Jordan, 223 F.3d 676 (7th Cir. 2000), which, while confirming that the prima facie determination is to be reviewed de novo, held that where the defendant's prima facie showing of discrimination and the prosecution's response are made simultaneously, the trial judge's determination is to be reviewed for clear error. Id. at 686.

5. Mahaffey, 162 F.3d at 484. The term "mixed question of fact and law" is often applied when a legal standard must be applied to a set of facts. At times, elements of fact and law are so entangled that the legal rule cannot easily be defined except in relation to the factual element. There are several reasons why this might be so. The rule might be new and still in the process of being worked out through application. There may be a failure to agree on a clear rule of law. See infra notes 122-32 and accompanying text. Or there may be resistance to abstracting the rule much beyond facts of cases for reasons of public policy. For example, Oliver Wendell Holmes argued that negligence was largely left to be redefined by the jury in each case, because the jurors bring to negligence actions the promise that "they will introduce into their verdict a certain amount ... of popular prejudice, and thus keep the administration of the law in accord with the wishes and feelings of the community." Oliver Wendell Holmes, Law in Science and Science in Law, 12 HARV. L. REV. 443, 459-60 (1899). On the nature of mixed questions in general, see, for example, FrANCIS BOHLEN, STUDIES IN THE LAW OF TORTS 602-06 (1926) (explaining why the jury system causes questions of law and fact to be "mixed"), and Clarence Morris, Law and Fact, 55 HARV. L. REV. 1303 (1942) (developing the essential differences between law and fact). Primarily for reasons of judicial economy, the legal consequence of the application of a legal standard to facts, as opposed to the prior question of what standard to apply to those facts, is generally held to be a question of fact. See Pullman-Standard v. Swint, 456 U.S. 273, 286 n.16 (1982) (holding that "ultimate fact," which is to say the legal significance drawn from the facts of the case, is not to be treated separately from the general facts of the case). 
trial proceedings, as "all seven African-American members of the jury venire were excused by the State" in a racially sensitive case of an African-American man charged with murdering a white couple. ${ }^{6}$

The second justification for the standard applied was the need for the appellate courts to maintain control over law declaration ${ }^{7}$ in this area of the law, as "factual scenarios will recur in this context, and de novo review would allow for a measure of consistency in the treatment of similar factual settings."

In Tolbert v. Page, ${ }^{9}$ the Ninth Circuit Court of Appeals, sitting en banc, took up the same question. The Tolbert court agreed that the question was a mixed question of law and fact, but came to the conclusion that the determination of the trial court was to be reviewed for clear error. ${ }^{10}$ The court based its decision on two grounds. First, it held that the allocation of responsibility between the trier of fact and the court of review for deciding a mixed question, which the court called the "law-fact distinction,"

6. Mahaffey, 162 F.3d at 484-85.

7. Henry Hart and Albert Sacks first divided the judicial decision into "law declaration" (the articulation of the rules of law), "fact identification" (the determination of the facts specific to the case at hand), and "law application" (the application of the rules of law to the facts of the case). Henry Hart \& Albert Sacks, The Legal Process: Basic Problems in the MAKING AND APPLICATION OF LAW 374-75 (William N. Eskridge, Jr. \& Philip P. Frickey eds., Foundation Press 1994) (1958). In a mixed question of fact and law, the trier of fact "instead of being asked to apply a statement of law declaration, is requested to formulate an ad hoc legal rule in conformity with a generalized standard." Note, Supreme Court Review of State Findings of Fact in Fourteenth Amendment Cases, 14 STAN. L. REV. 328, 336 (1962).

8. Mahaffey, 162 F.3d at 484.

9. 182 F.3d 677 (9th Cir. 1999) (en banc).

10. Id. at $681-82$.

11. Almost every procedural issue in a lawsuit depends on whether a matter is categorized as a question of fact or a question of law-from who the decisionmaker in the matter will be, to what evidence it will consider, to what standard a reviewing court will apply to its decision. Some would argue that the distinctions are simply a matter of allocation; questions of fact are for the jury or the judge acting as factfinder and questions of law are for the judge, with all the procedures that their respective roles entail. In this view, "fact" and "law" are merely placeholders for allocative decisions made on the basis of factors external to the nature of the questions themselves. See, e.g., Miller v. Fenton, 474 U.S. 104, 114 (1985) ("[T]he fact/law distinction at times has turned on a determination that ... one judicial actor is better positioned than another to decide the issue in question."); Kenneth Vinson, Disentangling Law and Fact: Echoes of Proximate Cause in the Workers' Compensation Coverage Formula, 47 ALA. L. REv. 723,743 (1996) ("[I]n cases where a jury is asked to apply the reasonable care standard to undisputed history, the truth is that issue is called a question of fact only because we chose to pass it to the jury."). More commonly, it is argued that there are inherent differences between fact and law that are related to, but not identical to, allocation. What these differences are, however, has been a source of intense debate at least since the arguments in the late nineteenth century over the nature of the jury's role in findings of negligence. See infra note 130 and accompanying text. Moreover, such arguments are complicated by, and often centered on, the vexing problem of "mixed" questions of law and fact. 
"better positioned" to make the call. ${ }^{12}$ In the matter of a Batson determination, the court held, the trial judge was in a better position because he could observe first-hand the prosecutor's and the stricken jurors' demeanor and attitude during voir dire. ${ }^{13}$

The Tolbert court was not terribly worried about the nature of the threat to the constitutional right at issue ${ }^{14}$ but like the Seventh Circuit Court of Appeals it also justified its decision on whether "probing appellate scrutiny will ... contribute to the clarity of legal doctrine." ${ }^{15}$ The court held that because Batson analysis is "a "factual inquiry' that 'takes into account all the possible explanatory factors' in the particular case," it is reliant on "multifarious, fleeting, special, narrow facts that utterly resist generalization." ${ }^{16}$ In other words, there is little chance for law declaration in the review of Batson determinations.

De novo review of the facts underlying the application of a constitutional standard is often characterized as the review of "constitutional fact." In describing the standard at work in constitutional fact review, courts use several interchangeable terms, including "de novo," "free," "independent," and "plenary" review. As they are used in these cases, they are all synonymous. ${ }^{17}$ Under constitutional fact doctrine, "[i]n determining whether [a] constitutional standard has been satisfied, the reviewing court must consider the factual record in full." ception to the default approach of the Federal Rules of Civil Procedure, under which the alignment between categories of fact and law and the standard of appellate review is very close; court findings of fact are reviewed under a "clearly erroneous" standard ${ }^{20}$ and findings of law are reviewed de novo. ${ }^{21}$ Under this scheme, "[i]deally, the ques-

\footnotetext{
12. Tolbert, 182 F.3d at 681.

13. Id. at 683 .

14. The dissenting judge worried, however. The dissent argued that when a mixed question "implicates constitutional rights," a less deferential standard of review is "favored." Id. at 689-90 (McKeown, J., dissenting).

15. Id. at 682 (citations omitted).

16. Id. at 684 (citations omitted).

17. Steven Alan Childress \& Martha S. Davis, Federal Standards OF Review $\S 2.14$, at 2-79 (3d ed. 1999).

18. Harte-Hanks Communications, Inc. v. Connaughton, 491 U.S. 657, 688 (1989).

19. New York Times Co. v. Sullivan, 376 U.S. 254, 285 (1964) ("We must "make an independent examination of the whole record,' so as to assure ourselves that the judgment does not constitute a forbidden intrusion on the field of free expression.") (citations omitted).

20. FED. R. CIV. P. 52(a).

21. Pullman-Standard v. Swint, 456 U.S. 273, 287 (1982).
} 
tion of the appropriate standard of review of any issue may be resolved by reference to this law/fact distinction." ${ }^{22}$ In recent years, the Supreme Court has "moved decisively" to ensure that this distinction is applied as consistently as possible, primarily in the name of lessening the burden on the docket of the federal appellate courts. ${ }^{23}$ Constitutional fact doctrine represents one of the few points of resistance to this trend of ever-greater deference to the findings of the trial court. ${ }^{24}$

This Note will seek to address two questions. The first concerns the actual scope of the application of constitutional fact. Some commentators have included several lines of constitutional cases under the rubric and analytical framework of constitutional fact, ${ }^{25}$ while others have contended that this framework is properly applied only to fact review in First Amendment cases, ${ }^{26}$ and even then find little to distinguish between constitutional fact review and other exceptions to the clear-error standard. ${ }^{27}$ This Note will demonstrate that a family of case lines can be clearly delineated as forming the basis of the doctrine but that the Supreme Court has grounded these lines in somewhat different rationales. In the last fifteen years, these lines have converged into a more coherent doctrine as the Court has sought to limit the expansion of constitutional fact to new areas of review.

The second question addressed in this Note is whether this now more coherent doctrine creates a constitutional fact standard that can both be successfully applied by lower appellate courts to questions of

22. Jeffrey C. Alexander, Note, The Law/Fact Distinction and Unsettled State Law in the Federal Courts, 64 TEX. L. REV. 157, 171 (1985).

23. Martin B. Louis, Discretion or Law: Appellate Review of Determinations That Rule 11 Has Been Violated or That Nonmutual Issue Preclusion Will Be Imposed Offensively, 68 N.C. L. REV. 733, 738 (1990).

24. Martin B. Louis, Allocating Adjudicative Decision Making Authority Between the Trial and Appellate Levels: A Unified View of the Scope of Review, the Judge/Jury Question, and Procedural Discretion, 64 N.C. L. REV. 993, 1005 (1986).

25. E.g., Frank R. Strong, The Persistent Doctrine of "Constitutional Fact," 46 N.C. L. REV. 223 (1968). Strong includes in his analysis lines of cases concerning both "procedural" liberties such as Fourth and Fifth Amendment rights reviewed on habeas grounds and the "substantive" civil liberties addressed in First Amendment cases. I have adopted the terms "procedural" and "substantive" to structure my own analysis in this Note.

26. E.g., Steven Alan Childress, Constitutional Fact and Process: A First Amendment Model of Censorial Discretion, 70 TUL. L. REV. 1229, 1241 (1996) (arguing that free speech interests justify applying a constitutional fact, as opposed to a clear-error, standard of review to First Amendment cases).

27. Id. at 1240 (noting that the abundance of cases that "merely restate legal conclusions or mixed law-fact questions fall outside complete fact-finding protections, such as the clearly erroneous standard of Federal Rule 52(a) ... are not revolutionary or particularly necessary as a separate exception"). 
first impression and act to limit the instances in which these courts will expand plenary review to new areas of the law.

The first part of this Note will seek to define the scope of constitutional fact review. Section A of this part will review the basic features of the doctrine and its relationship to the federal rules. Section B will examine the three lines of cases-administrative, procedural, and substantive-from which the modern doctrine of constitutional fact has emerged. It is within this historical discourse that the justification for independent review of facts has been articulated.

The Supreme Court has utilized three primary rationales for applying plenary review to what would otherwise be regarded as issues of fact requiring only "clear error" review. These rationales can be seen at work in Mahaffey, with its focus on the constitutional right endangered by discrimination in jury selection and the opportunity for law declaration in de novo appellate review; in Tolbert, with its attention to the greater trustworthiness of the trial court's vantage point; and again in the law-declarative opportunity, or lack thereof, that appellate review presents.

These reasons can be recast as arguments that independent review is or is not necessary (1) because the nature of the question itself is that of a mixed question of fact and law, the law aspect of which is given content only through application; (2) because the constitutional value at stake is so great and so vulnerable; and (3) because the trier of fact, because of issues of either competence or bias, cannot be trusted to make the decision.

These rationales exist to some degree in all findings of constitutional fact. For example, the argument that review is necessary to protect a constitutional right includes an implicit argument that the trier of fact cannot be trusted to protect that right on its own. ${ }^{28}$ However, the relationship between the three rationales varies in particular judicial decisions. In Section C of Part I, I will describe the development of constitutional fact doctrine and how the competing rationales for the doctrine have come to be prioritized in the recent era. In the modern era, decisions concerning "procedural" rights have focused primarily on the nature of the question, ${ }^{29}$ while both the remnants of

28. See infra notes $161-73$ and accompanying text.

29. E.g., Ornelas v. United States, 517 U.S. 690, 697 (1996) ("[T] he legal rules for probable cause and reasonable suspicion acquire content only through application. Independent review is therefore necessary if appellate courts are to maintain control of, and to clarify, the legal principles."); Thompson v. Keohane, 516 U.S. 99, 113 (1995) (holding that determination of whether a suspect is "in custody" for Miranda purposes is a mixed question of fact and law subject to "in- 
the now mostly dormant administrative line and the still-vital "substantive" First Amendment line have looked first to the nature of the threatened right. ${ }^{30}$ This focus on constitutional right has been the subject of sustained and influential academic criticism. ${ }^{31}$ These critics have worried that establishing a duty to review all cases in which constitutionally based standards of law were applied to specific facts would either drown the courts or eviscerate review. ${ }^{32}$ Henry Monaghan, for example, argued that the court could never successfully articulate why some constitutional rights were deserving of the protection provided by independent review while others were not, and therefore could never limit the application of the doctrine on the basis of the nature of the right. ${ }^{33}$

These critics have suggested various limiting principles to the constitutional fact doctrine. Monaghan proposes that the primary test in the application of plenary review should be whether the issue at hand concerns the sort of mixed question of fact and law where the appellate court is just as competent as the trial court to define and apply the law and where appellate control of this process of definition is necessary. ${ }^{34}$ Under the influence of this approach, the "procedural" and "substantive" lines of constitutional fact doctrine have been largely reconciled into a single standard, in which the nature of the question rather than the nature of the right is the primary focus. For

dependent review"); Miller v. Fenton, 474 U.S. 104, 114 (1985) (arguing, in regard to the review of determinations of the voluntariness of confessions, that where the "legal principle can be given meaning only through its application to the particular circumstances of a case, the Court has been reluctant to give the trier of fact's conclusions presumptive force and, in so doing, strip a federal appellate court of its primary function as an expositor of law"); Container Corp. of Am. v. Franchise Tax Bd., 463 U.S. 159, 176 (1983) (declaring that not "every colorable claim" can be reviewed de novo).

30. E.g., Bose Corp. v. Consumers Union of United States, Inc., 466 U.S. 485, 502 (1984) (arguing, in holding that determinations of actual malice in defamation cases must be reviewed de novo, that "the constitutional values protected by the rule make it imperative that judgesand in some cases judges of this Court-make sure that it is correctly applied"); Connick v. Myers, 461 U.S. 138, 142-49 (1983) (weighing the public employee's right to comment on office policy against the state's interest in effective employment); New York Times Co. v. Sullivan, 376 U.S. 254, 285 (1964) ("We must 'make an independent examination of the whole record,' so as to assure ourselves that the judgment does not constitute a forbidden intrusion on the field of free expression." (quoting Edwards v. South Carolina, 372 U.S. 229, 235 (1963))).

31. These critics are best represented in the administrative law context by John Dickenson. E.g., John Dickenson, Crowell v. Benson: Judicial Review of Administrative Determinations of Questions of "Constitutional Fact," 80 U. PA. L. REV. 1055, 1072-82 (1932). In the First Amendment context they are legion, but the most influential analysis and critique is Henry P. Monaghan's Constitutional Fact Review, 85 ColuM. L. Rev. 229 (1985).

32. Dickenson, supra note 31, at 1077; Monaghan, supra note 31, at 264.

33. Monaghan, supra note 31, at 264.

34. Id. at 271 . 
example, in Miller v. Fenton, ${ }^{35}$ Justice O'Connor announced a new three-factor test for when to apply plenary review to fact determinations: stare decisis; "the nature of the inquiry itself"; and the likelihood of bias on the part of the factfinder..$^{36}$

Having defined the scope of constitutional fact doctrine, this Note will critique in Part II the current manifestation of the doctrine. Constitutional standards are often defined through their application (one might say that this is a universal feature of law) and an effective limiting principle for when constitutional fact review should be applied must be established if the doctrine is to remain an effective tool by which appellate courts can fully protect constitutional rights. The doctrine adopted by the current Court seems to work well for the Supreme Court itself, if the Court's own comfort in expanding the range of questions to which it has applied constitutional fact review is any indication. But it is not yet clear if this willingness to expand the scope of application of constitutional fact reflects the Court's confidence that it has created an effectively self-limiting doctrine, or only the Court's confidence in its own self-discipline in monitoring and regulating any further expansion.

\section{Definition And Scope of CONSTITUtional FACT Doctrine}

This Note primarily addresses the scope of the constitutional fact doctrine's application. This question is best initially explored by describing the three lines of cases in which the doctrine of constitutional fact has been developed. The meaning of the term "constitutional fact" as it is used in this Note must first be defined, however.

\section{A. What is Constitutional Fact?}

1. Distinguished from Legislative Fact. One must distinguish constitutional fact doctrine in the sense of a standard of review from another common use of the term "constitutional fact" or "constitutional factfinding" as referring to the legislative facts that 
form the premises for constitutional rulings. ${ }^{37}$ An example of the latter can be seen in Lochner v. New York, ${ }^{38}$ where the Court based its finding of a right to contract in part on its view of the real world respective bargaining positions of management and labor. ${ }^{39}$

The terms "adjudicative fact" and "legislative fact" were introduced by Kenneth Culp Davis in his 1942 article, An Approach to Problems of Evidence in the Administrative Process. ${ }^{40}$ Professor Davis distinguished between "facts concerning immediate parties-what the parties did, what the circumstances were, what the background conditions were," which he called adjudicative, and questions of policy, which he called legislative. ${ }^{41} \mathrm{He}$ later refined this distinction:

Adjudicative facts usually answer the questions of who did what, where, when, how, why, with what motive or intent; adjudicative facts are roughly the kind of facts that go to a jury in a jury case. Legislative facts do not usually concern the immediate parties but are general facts which help the tribunal decide questions of law and policy and discretion. ${ }^{42}$

As the Eighth Circuit Court of Appeals noted in United States v. Gould, "Legislative facts are established truths, facts or pronouncements that do not change from case to case but apply universally, while adjudicative facts are those developed in a particular case." ${ }^{44}$ The facts reviewed under constitutional fact doctrine are adjudicative facts, specific to the case at hand. ${ }^{45}$

37. One of the most well-known accounts of the latter usage is that of David L. Faigman, "Normative Constitutional Fact-finding": Exploring the Empirical Component of Constitutional Interpretation, 139 U. PA. L. REV. 541 (1991) (arguing that empirical research forces courts to attend to, and to be accountable for, value judgments underlying their factual jurisprudence). Such premises are to be distinguished from legislative facts, which serve as the basis of lawmaking by Congress and must be reviewed more deferentially.

38. 198 U.S. 45 (1905).

39. Id. at 56.

40. 55 HARV. L. REV. 364 (1942).

41. Id. at 402 .

42. Kenneth Culp Davis, Administrative Law Text § 7.03, at 160 (3d ed. 1972).

43. 536 F.2d 216 (8th Cir. 1976).

44. Id. at 220; see also Robert E. Keeton, Legislative Facts and Similar Things: Deciding Disputed Premise Facts, 73 MINN. L. REV. 1, 11 (1988) (suggesting the term "premise facts" as an alternative to refer to any fact that serves as the premise for a reasoned decision of law). Judge Keeton's term has the virtue of emphasizing that the procedural treatment of a fact as an adjudicative or legislative fact does not depend on the nature of the fact in dispute, but rather on its function in the court's process (both mental and judicial).

45. Monaghan, supra note 31, at 230-31 n.16 ("The adjudicative facts decisive of constitutional claims usually pertain to the concrete application of a statute or regulation being chal- 
2. Constitutional Fact Review and the Federal Rules of Civil Procedure. Under Federal Rule of Civil Procedure 52(a), "[f]indings of fact, whether based on oral or documentary evidence, shall not be set aside unless clearly erroneous, and due regard shall be given to the opportunity of the trial court to judge of the credibility of the witnesses." ${ }^{46}$ In the context of direct appeals in civil cases, constitutional fact seems to contradict this rule. For example, the question in Bose Corp. v. Consumers Union of United States, Inc., ${ }^{47}$ as posed by the Supreme Court, was whether Rule 52(a) prohibits the independent review prescribed by New York Times Co. v. Sullivan ${ }^{48}$ in a defamation case concerning whether a false statement was made with actual malice. ${ }^{49}$ Although such a determination might seem to be the sort of credibility finding explicitly mentioned as deserving deference in Rule 52(a), ${ }^{50}$ the Court found that independent review was not precluded. ${ }^{51}$ As I will discuss in greater detail, ${ }^{52}$ the Court would later strive to characterize the outcome in Bose as consistent with the trial court's findings on credibility, and so consistent with Rule 52(a). ${ }^{53}$

Independent review does not mean that the reviewing court can review the factual record as a whole, but it must review any part of the record relating to the legal question at issue..$^{54}$ As the Court held in Bose, "The independent review function is not equivalent to a 'de novo' review of the ultimate judgment itself, in which a reviewing court makes an original appraisal of all the evidence to decide

lenged on constitutional grounds. Constitutional fact review thus does not implicate the legislative facts that underlie the statute or regulation in its general application." (citations omitted)).

46. FED. R. CIV. P. 52(a). The "clearly erroneous" standard is itself somewhat vaguely defined. See, e.g., Anderson v. City of Bessemer City, 470 U.S. 564, 573-74 (1985) ("If the district court's account of the evidence is plausible in light of the record viewed in its entirety, the court of appeals may not reverse it even though convinced that had it been sitting as the trier of fact, it would have weighed the evidence differently."); United States v. United States Gypsum Co., 333 U.S. 364, 395 (1948) ("A finding is 'clearly erroneous' when despite evidence to support it, the reviewing court on the entire evidence is left with the definite and firm conviction that a mistake has been committed."). As can be seen from both of these definitions, the major feature of the standard is deference to the trial court.

47. 466 U.S. 485 (1984).

48. 376 U.S. 254, 285 (1964).

49. Bose, 466 U.S. at 487.

50. Bose, 466 U.S. at 515 (Rehnquist, J. dissenting).

51. Id. at 510-11.

52. See infra notes $158-59$ and accompanying text.

53. See Hurley v. Irish-American Gay, Lesbian \& Bisexual Group, 515 U.S. 557, 567 (1995) (explaining that independent review "does not limit our deference to a trial court on matters of witness credibility").

54. ChILDRESS \& DAVIS, supra note $17, \S 2.14$. 
whether or not it believes that judgment should be entered for plaintiff." 55

The equivalent of Rule 52(a) in habeas corpus cases is 28 U.S.C. $\S 2254(\mathrm{~d})$. Prior to the enactment of the Antiterrorism and Effective Death Penalty Act of 1996 (AEDPA), the clear rule was that an independent federal inquiry into the state record was required where the inquiry was a mixed question subject to plenary review. ${ }^{56}$ As will be discussed in the next section, the passage of AEDPA has left the nature of the application of constitutional fact doctrine in habeas corpus cases in doubt.

3. Standard of Review and the Nature of the Factfinder. In cases on direct appeal from federal courts, while the specific nature of the right at issue will have some effect on how constitutional fact review is applied, the standard of review is the same regardless of the nature of the finder of fact being reviewed.

The standard of review in habeas petitions is governed by the AEDPA, under which Title 28 §2254(d) now reads:

An application for a writ of habeas corpus on behalf of a person in custody pursuant to the judgment of a State court shall not be granted with respect to any claim that was adjudicated on the merits in State court proceedings unless the adjudication of the claim-

55. Bose, 466 U.S. at 514 n. 31.

56. Miller v. Fenton, 474 U.S. 104, 110 (1985).

57. Bose, 466 U.S. at 501 ("[T]he rule of independent review assigns to judges a constitutional responsibility that cannot be delegated to the trier of fact, whether the factfinding function be performed in the particular case by a jury or by a trial judge."). Where the constitutional fact doctrine does not apply, the deferential standard to be applied to the findings of the trier of fact is in theory different for findings by a trial judge and by a jury. The judge is reviewed under a clearly erroneous standard, while the jury is reviewed under a clear weight of the evidence standard. The difference between these standards is slight, however, and hard to articulate. As a result, courts will often analyze jury findings under the clearly erroneous standard. Note, Amplifying Bose Corp. v. Consumers Union: The Proper Scope of De Novo Appellate Review in Public Person Defamation Cases, 57 FordHAM L. REv. 579, 582 n.30 (1989); see also Ornelas v. United States, 517 U.S. 690, 695-97 (1996) (holding that plenary review applies in the same way to procedural-rights cases being heard on habeas and on direct appeal, and holding that "reasonable suspicion" and "probable cause" determinations are subject to plenary review). Ornelas was responding to the Seventh Circuit Court of Appeals' position that the Supreme Court's rule in Miller v. Fenton, 474 U.S. 104, 110 (1985), applying plenary review to voluntariness of confession determinations in habeas corpus appeals, did not necessarily apply to cases on direct appeal. United States v. Baldwin, 60 F.3d 363, 365 (7th Cir. 1995). Depending on what effect AEDPA is found to have on the application of constitutional fact doctrine to habeas corpus cases, Ornelas may now simply stand for the rule that plenary review is to be applied to those procedural rights cases on direct appeal to which it has been held to apply in the past in either habeas or direct appeals. 
(1) resulted in a decision that was contrary to, or involved an unreasonable application of, clearly established Federal law, as determined by the Supreme Court of the United States; or

(2) resulted in a decision that was based on an unreasonable determination of the facts in light of the evidence presented in the State court proceeding. ${ }^{58}$

Section 2254(d)(1) was interpreted by the Supreme Court in Williams v. Taylor. ${ }^{59}$ The majority's view on the meaning of the AEDPA was given in a concurrence by Justice O'Connor, while Justice Stevens wrote the decision on the narrower question of whether the state court's decision was contrary to the federal test for ineffective counsel as established by the Supreme Court. ${ }^{60}$ Justice O'Connor held that the "contrary to" and "unreasonable application" clauses of the section are to be read independently. ${ }^{61}$ Thus, the Court distinguished the effect of the AEDPA on questions of law from its effect on questions of the application of the law to the facts. ${ }^{62}$

Under Williams, a state court's decision is contrary to Supreme Court precedent if it "arrives at a conclusion opposite to that reached by this Court on a question of law," or if it arrives at an opposite result to a Supreme Court precedent that is "materially indistinguishable" on the facts. ${ }^{63}$ An application of Supreme Court precedent is unreasonable if the state court identifies the correct rule of law but "unreasonably applies it to the facts," or where the state court extends the rule of the precedent "to a new context where it should not apply" or fails to extend it where it should apply. ${ }^{64}$ The court gives lit-

58. 28 U.S.C. $§ 2254(d)$ (Supp. IV 1998).

59. 120 S. Ct. 1495 (2000).

60. Id. at 1512 .

61. Id. at 1519 (O'Connor, J., concurring). Justice Stevens argued that the clauses ought to be read together as expressing merely a "mood" of respect for state court decisions, rather than a more deferential standard of review. Id. at 1509.

62. The Supreme Court, 1999 Term-Leading Cases, 114 HARV. L. REV. 319, 322 (2000) [hereinafter Supreme Court].

63. Williams, 120 S. Ct. at 1519 (O'Connor, J., concurring).

64. Id. at 1520 (O'Connor, J., concurring). Rejecting the Fourth Circuit Court of Appeals' view that under $\S 2254(\mathrm{~d})(1)$ an application is unreasonable only where all reasonable jurists would agree that it is unreasonable, Green v. French, 143 F.3d 865, 870 (4th Cir. 1998), the Court held that the standard of reasonableness is an objective one. Williams, $120 \mathrm{~S}$. Ct. at 1521 (O'Connor, J., concurring). In so doing, the Court probably made the standard of review less deferential than Congress intended. There is evidence in the legislative record that Congress intended the AEDPA to enact the rule, suggested by Justice Thomas in Wright $v$. West, 505 U.S. 277, 291 (1992), that federal courts may not apply new rules that are "susceptible to debate 
tle help in defining the term "unreasonable," beyond noting that a writ of habeas corpus cannot be issued where the reviewing court "concludes in its independent judgment that the ... decision applied clearly established federal law erroneously or incorrectly. Rather, that application must also be unreasonable." $" 65$

As the Court has not ruled directly on the question, it is not possible to say definitively whether a constitutional fact determination, as a mixed question of fact and law, would be subject to the "contrary to" or the "unreasonable" analysis. However, it is likely that the "unreasonable" standard would be applied. Justice O'Connor indicates that she would define at least one such determination, that of the voluntariness of a confession, as an "application of constitutional law to fact," ${ }^{66}$ indicating that the unreasonable application clause would apply. ${ }^{67}$ However, as I will

among reasonable minds" retroactively to habeas petitions. Supreme Court, supra note 62, at 325.

65. Williams, $120 \mathrm{~S}$. Ct. at 1521-22 (O'Connor, J., concurring). The Ninth Circuit Court of Appeals has recently solved the problem by ruling that the "unreasonable application" standard is equivalent to the "clearly erroneous" standard applied to factual determinations by district courts. Van Tran v. Lindsey, 212 F.3d 1143, 1153-54 (9th Cir. 2000). This ruling seems to be a bow to the notion that there are really only two standards of review possible, deferential and nondeferential. See supra note 2 and accompanying text.

66. Williams, $120 \mathrm{~S}$. Ct. at 1521-22 (O'Connor, J., concurring).

67. It might be argued that at least some constitutional fact questions are actually determinations of fact governed by $\S 2254$ (d)(2). Under the "two-tiered" approach currently favored by the Court, see infra notes 132-35, 195 and accompanying text, some constitutional fact questions can be both questions of fact and of application of law to fact at the same time. In one of the few cases interpreting the application of $\S 2254(\mathrm{~d})(2)$ to a constitutional fact determination, the Eighth Circuit Court of Appeals reversed a district court holding that the review of the determination of whether a suspect was "in custody" for Miranda purposes was governed by $\S$ 2254(d)(2), holding that (d)(1) applied instead. Evans v. Rogerson, 223 F.3d 869, 872 (8th Cir. 2000). In an example of the two-tiered approach, the Supreme Court has broken the "in custody" determination into "[t]wo discrete inquiries." Thompson v. Keohane, 516 U.S. 99, 112 (1995). The first is the purely factual determination of the circumstances surrounding the interrogation of the defendant. The second is the determination of whether a reasonable person would have felt himself to be "in custody" in those circumstances. Id. The Evans court found that the underlying facts were not in dispute, and so only the latter question, a question of application, was at issue. Evans, 223 F.3d at 872.

If $\S 2254(d)(2)$ were to be found to apply, it is unclear whether the analysis would differ from that under $\S 2254$ (d)(1) in any case. At least one circuit has found that whether $\S(d)(1)$ or $\S(d)(2)$ is applied "makes no difference for purposes of the standard of review," as the "unreasonable" standard of (d)(1) is the same as that of (d)(2). Torres v. Prunty, 223 F.3d 1103, 110708 (9th Cir. 2000) (following Van Tran in applying a clear error standard). On the other hand, $\S 2254(\mathrm{e})(1)$ requires a habeas court to presume that factual determinations made by the state court are correct and places the burden on the petitioner to rebut that presumption by clear and convincing evidence. 28 U.S.C. \$ 2254(e)(1) (Supp. IV 1998). Together, \$§ 2254(e)(1) and (d)(2) make it extremely difficult for a federal court to overturn a state court's finding of fact. See, e.g., Givens v. Yukins, No. 98-2429, 2000 U.S. App. LEXIS 31952, at*27-30 (E.D. Mich. Dec. 5, 
discuss in greater detail ${ }^{68}$ it is often difficult to draw a clear line between rules and the application of rules. Justice Stevens makes this point in Williams, noting:

[A]n erroneous conclusion that particular circumstances established the voluntariness of a confession ... may well be described either as "contrary to" or as an "unreasonable application of" the governing rule of law. In constitutional adjudication, as in the common law, rules of law often develop incrementally as earlier decisions are applied to new factual situations. But rules that depend on such elaboration are hardly less lawlike than those that establish a bright-line test. $^{69}$

In any case, it is not clear how much it matters whether questions of constitutional fact are treated as questions of law or of application, as under either approach the review of state court decisions must be deferential. It is therefore likely that federal courts will no longer apply plenary review to questions of constitutional fact in habeas cases. At the same time, it is also likely that state appellate courts must apply plenary review themselves to constitutional fact determinations where the Supreme Court has determined that such review is constitutionally required, as a failure to do so would be to act contrary to Court precedent. In Williams itself, in the analogous matter of the application of the Strickland test for ineffective counsel claims, the Court found that the state court had failed both in its understanding of the rule and in its application of the rule, in part because the court "failed to evaluate the totality of the available mitigation evidence." 70 Failure to evaluate evidence as thoroughly as a constitutional rule requires would therefore appear to qualify as unreasonable application of a rule. ${ }^{71}$

However, under AEDPA, state courts are bound only by federal law "as determined by the Supreme Court of the United States." 72 This means that lower federal courts cannot review state courts' failure to apply constitutional fact review where such review has not been established by the Supreme Court, even where federal courts of

2000) (applying $\S \S 2254(d)(2)$ and (e)(1) in finding reasonable a state court's crediting of police witnesses over a defendant's testimony that a waiver of Miranda rights was not voluntary).

68. See infra Part IIB.

69. Williams, $120 \mathrm{~S}$. Ct. at 1508 (citations omitted).

70. Id. at 1515 .

71. Supreme Court, supra note 62, at 328-29.

72. Williams, 120 S. Ct. at 1523. 
appeals have prescribed constitutional fact review. ${ }^{73}$ The potential for the expansion of the scope of application of constitutional fact review is therefore severely limited in habeas cases.

4. Scope of Review of Factual Record. The depth to which the appellate court should delve into the factual record has been a matter of continuing dispute, particularly in the First Amendment line of cases. The source of this dispute was the Bose decision's lack of clarity about how to define "review of the whole record," particularly in regard to the trier's of facts credibility findings. The Bose Court said that independent review of actual malice was compatible with Rule 52(a)'s mandate that findings of fact should be reviewed for clear error, because actual malice is a mixed question in which "the reasoning by which a fact is 'found' crosses the line between application of those ordinary principles of logic and common experience which are ordinarily entrusted to the finder of fact into the realm of a legal rule upon which the reviewing court must exercise its own independent judgment." ${ }^{, 74}$ The Court did not, however, explain how its decision to reverse the jury's determination that the writer of the article at issue acted with actual malice was consistent with Rule 52(a)'s further mandate that due regard be given to the trial court's "opportunity to judge the credibility of witnesses." 75

Over time, the Supreme Court "clarified" Bose, holding that the reviewing court was to give deference to the credibility determinations of the trier of fact when reviewing the factual record. ${ }^{76}$ However,

73. Id.

74. Bose, 466 U.S. 485, 501 n.17 (1985).

75. See Scott M. Matheson, Jr., Procedure in Public Person Defamation Cases: The Impact of the First Amendment, 66 TEX. L. REV. 215, 274-75 (1987) ("The Court in Bose . . ducked the hard question of how an appellate court is supposed to conduct a meaningful independent review of the evidence when actual malice hinges on the publisher's subjective state of mind."). Justice Rehnquist, joined by Justice O'Connor, seized upon the issue of credibility in his dissent in Bose. He pointed out that the constitutional fact doctrine had never before been applied to actual state-of-mind determinations by the finder of fact. Bose, 466 U.S. at 517 (Rehnquist, J., dissenting). In other applications of the doctrine in First Amendment cases, courts have considered what the reaction of a "reasonable person" to speech would be, a determination that appellate courts were as competent as or more competent than trial courts to make. Id. at 515-17.

76. E.g., Harte-Hanks Communications, Inc. v. Connaughton, 491 U.S. 657, 689 n.35 (1989) (citations omitted):

[Petitioner] contends, however, that this Court did reject the trial court's credibility determination in Bose. We disagree with this reading of Bose. In Bose we accepted the trial court's determination that the author of the report at issue did not provide credible testimony concerning the reason for his choice of words and his understanding of the meaning of the word "about." Unlike the District Court, however, we were unwilling to infer actual malice from the finding that the witness "refused to admit 
in trying to reconcile Bose and Rule 52(a), the courts of appeals faced the dilemma that when, as in most cases, the jury's decision was a general verdict, there was no way for the appellate court to know exactly what the jury's credibility determinations were. ${ }^{77}$ Some courts solved the problem by "draw[ing] all reasonable inferences in favor of the verdict of the jury, and then determin[ing] whether that evidence demonstrates clearly and convincingly that the defendant acted with actual malice." 78 Such an approach would have made constitutional fact review little different from a sufficiency of evidence determination, which was probably the result the courts applying this approach hoped to achieve. ${ }^{79}$ Courts that were uncomfortable with de novo review of fact used the dilemma created by applying both Bose and Rule 52(a) as an opportunity largely to vitiate plenary review.

This avenue for limiting Bose was blocked by the Supreme Court in Harte-Hanks Communications, Inc. v. Connaughton. ${ }^{80}$ The Court made it clear that, while credibility determinations were to be reviewed for clear error, constitutional fact review must be review "of the entire factual basis for a jury's finding ... a review that examines both the subsidiary facts underlying the jury's finding of actual malice and the jury's ultimate finding of actual malice itself." ${ }^{81}$ As one court of appeals opinion has put it, this means that appellate courts "must figure out, as best we can from the cold record, which evidence the jury accepted as credible, and which it discarded. Then we must determine whether the believed evidence establishes actual malice." $\$ 2$

[his mistake] and steadfastly attempted to maintain that no mistake had been madethat the inaccurate was accurate."

This process of clarification was led by Justices Rehnquist and O'Connor, who thereby remade constitutional fact doctrine in the image of their dissent in Bose. For a discussion of this process, see infra notes $154-60$ and accompanying text.

77. Note, supra note 57 , at 596.

78. Tavoulareas v. Piro, 759 F.2d 90, 109 (D.C. Cir. 1985), rev'd, 817 F.2d 762 (D.C. Cir. 1987) (en banc); see also Harte-Hanks, 842 F.2d at 840-41, aff'd, 491 U.S. 657 (1989) (reviewing the record and finding the jury's determinations and inferences were not clearly erroneous).

79. See Tavoulareas, 759 F.2d at 147 (Wright, J., dissenting):

[The majority's] approach renders the independent appellate review promised by Bose a mirage. Independent review of the record devolves into review of the pool of pre-selected inferences that cut against the defendant. It comes as no surprise, then, that, at the point for the majority's exercise of independent review, the outcome has already been largely decided against the defendant.

80. 491 U.S. 657 (1989).

81. Id. at 697 (Scalia, J., concurring) (quoting the "first and most significant" of the questions on which certiorari had been granted).

82. Eastwood v. Nat'l Enquirer, Inc., 123 F.3d 1249, 1252 (9th Cir. 1997). The Court prescribes a similar two-step process in cases reviewing probable cause. The reviewing court is to 
Harte-Hanks therefore makes clear that the dilemma of reconciling review of the whole record and deference for credibility determinations cannot be side-stepped by assuming that "the jury made all the supportive findings it reasonably could have made." ${ }^{\prime 3}$ It did not, however, solve this dilemma. In Harte-Hanks itself the jury's decision was based on three special interrogatories, ${ }^{84}$ but it is not yet clear what courts should do when faced with a general verdict in which credibility determinations are truly indeterminable. ${ }^{85}$

Some courts and commentators continue to try to limit subtly the facts to which constitutional fact review will be applied, although the distinctions drawn are more apparent than real. In an en banc decision in $1997,{ }^{86}$ the Eighth Circuit Court of Appeals returned to the problem of reconciling Rule 52(a) and independent review, announcing that it would review findings of "critical" facts de novo and "noncritical" facts for clear error. ${ }^{87}$ In so doing, the court was overturning an earlier panel decision in the case ${ }^{88}$ which had sided with the Ninth Circuit's approach of "pure" de novo review."

It is doubtful that this distinction between constitutional fact review as "pure" de novo review and as review of "critical" facts is

treat deferentially the trial court's determination of the historical facts leading up to the search, as such findings will be tightly bound up with credibility determinations. But the reviewing court must then weigh these findings on its own and find "whether these historical facts, viewed from the standpoint of an objectively reasonable police officer, amount to reasonable suspicion or to probable cause." Ornelas v. United States, 517 U.S. 690, 696 (1996).

83. Harte-Hanks, 491 U.S. at 700 (Scalia, J., dissenting).

84. Id. at 690 .

85. See Eastwood, 123 F.3d at 1252 ("Without a transcript of the jury's deliberations, we can only guess which facts (aside from those essential to the verdict) it must have believed. In another case, this task might well prove impossible, forcing us to rethink our deferential-yet-denovo approach.").

86. Families Achieving Independence \& Respect v. Neb. Dep’t of Soc. Serv., 111 F.3d 1408 (8th Cir. 1997) (en banc).

87. Id. at 1411. As one commentator defined them:

$[\mathrm{C}]$ ritical facts are those factual findings of a trial court where the finding of fact and a conclusion of law as to a federal right are so intermingled as to make it necessary to analyze the facts in order to decide the federal constitutional question. Examples of critical facts in free speech cases include findings regarding whether particular remarks are fighting words; findings as to what is patently offensive under the community standard obscenity test; and findings regarding the existence of actual malice.

L. Steven Grasz, Critical Facts and Free Speech: The Eighth Circuit Clarifies Its Appellate Standard of Review for First Amendment Free Speech Cases, 31 Creighton L. REV. 387, 395 (1998).

88. Families Achieving Independence \& Respect v. Neb. Dep't of Soc. Serv., 91 F.3d 1076 (8th Cir. 1996).

89. Gerritsen v. City of Los Angeles, 994 F.2d 570, 575 (9th Cir. 1993) (adopting de novo review of First Amendment questions because these questions present mixed questions of law and fact). 
more than a difference in emphasis. It is true that decisions in some circuits have emphasized that plenary review extends only to facts concerning the constitutional right at issue, ${ }^{90}$ while most circuits do not make this careful distinction between critical and noncritical facts, referring only to the need for undeferential review of the whole record. ${ }^{91}$ Steven Grasz, a supporter of the Eighth Circuit's distinction, points to the Supreme Court's definition of constitutional fact in Hurley v. Irish-American Gay, Lesbian and Bisexual Group of Boston $^{92}$ to support the former view. ${ }^{93}$ In Hurley, Justice Souter wrote for the majority:

The requirement of independent appellate review ... does not limit our deference to a trial court on questions of witness credibility, but ... requires us to review the finding of facts by a State court... where a conclusion of law as to a Federal right and a finding of fact are so intermingled as to make it necessary, in order to pass upon the Federal question, to analyze the facts. ${ }^{94}$

This is an unremarkable definition of constitutional fact, and it does not indicate a narrowing of the scope of review. Within a few lines of this passage, Souter writes both that "we are obliged to make a fresh examination of crucial facts" and that "our obligation is to make an independent examination of the whole record," without giving any indication that he believes these to be somehow different standards. ${ }^{95}$ As the Court noted in Bose, independent review is not the same thing as de novo review in the sense of an original appraisal of all evidence in a case. Review is limited to facts relevant to the constitutional question. ${ }^{96}$ There is no evidence that courts that refer to "independent examination of the whole record" seek to review facts unrelated to the constitutional question on appeal.

90. E.g., Peter Scalamandre \& Sons, Inc. v. Kaufman, 113 F.3d 556, 560 (5th Cir. 1997) (noting that independent review "extends only to the ultimate factual finding of actual malice; we do not conduct de novo review of the jury's determination of preliminary factual issues or questions of credibility"); AIDS Action Comm. of Mass., Inc. v. Mass. Bay Transp. Auth., 42 F.3d 1, 7 (1st Cir. 1994) (emphasizing facts in the record that relate to a "mixed fact/law issue involving a core First Amendment concern").

91. E.g., Bery v. City of New York, 97 F.3d 689, 693 (2d Cir. 1996) ("[W]e are required to make an independent examination of the record as a whole without deference to the factual findings of the trial court.").

92. 515 U.S. 557 (1995).

93. Grasz, supra note 87 , at 395 .

94. Hurley, 515 U.S. at 567 (internal quotation marks and citations omitted).

95. Id. at 567-68 (internal quotation marks and citations omitted).

96. Bose Corp. v. Consumers Union, 466 U.S. 485, 514 n.31 (1984). 
However, the definition of the field of relevant facts is a matter to be determined by the reviewing court. The distinction between a "crucial fact" and a "pure de novo" standard does reflect the degree to which a particular court desires to be deferential to the trial court, which will partly determine the breadth of the field to which it will apply plenary review. Moreover, Grasz's reliance on the passage in Hurley justifying the application of constitutional fact review by the mixed nature of the fact to be determined foreshadows the discussion below, in which it will become clear that those who wish to limit the application of constitutional fact review will focus on the nature of the question being reviewed, rather than on the nature of the right being protected.

\section{B. Development of the Rationales of Constitutional Fact Doctrine}

As stated in the introduction, constitutional fact review has found justification in three rationales: 1) the nature of the constitutional right at issue; 2) the mixed nature of the question of law at issue; and 3) distrust of the trier of fact. Constitutional fact initially emerged in the administrative law context at least in part out of concern for procedural safeguards of both economic and individual constitutional rights. As the administrative line died out, a line of cases developed that applied independent fact review out of concern for both individual procedural rights and the need for the appellate courts to guide issues in which law finds meaning only through its application to facts. Over time, the latter rationale came to dominate the "procedural line." However, another family of cases emerged in which independent review was again primarily justified by potential threats to individual liberties, this time substantive First Amendment rights.

1. Administrative Law Line. From the mid-nineteenth century, the rule in American law was that when an administrative tribunal acted as a factfinder, judicial review was limited to whether the findings were supported by substantial evidence. ${ }^{98}$ In the 1920 s and 1930s, however, this rule was challenged by a new doctrine of "constitutional fact," under which the federal courts were to review

97. See infra notes $170-72$ and accompanying text.

98. Louis L. Jaffe, Judicial Review: Constitutional and Jurisdictional Fact, 70 HARV. L. REV. 953, 953 (1957) ("Judicial control of the finding of fact is limited to the inquiry whether there is substantial evidence."). 
de novo determinations of fact that "are fundamental or 'jurisdictional,' in the sense that their existence is a condition precedent to the operation of the statutory scheme." 99

The idea that there must be judicial review of the determination of facts that bring a matter under the regulatory authority of an administrative body has existed in the common law from the seventeenth century. ${ }^{100}$ The enabling statute upon which jurisdiction is based identifies which "jurisdictional facts" must exist for an administrative body to have regulatory jurisdiction. When the enabling law is the Constitution itself, such facts can be called "constitutional facts." ${ }^{101}$ For example, the Court in Crowell v. Benson, ${ }^{102}$ a case concerning a claim under the Longshoremen's and Harbor Workers' Compensation Act, reviewed two questions of fact: 1) whether the injury at issue took place on the navigable waters of the United States, as the constitutional authority for Congress to pass the act in the first place was based on Congress's authority to legislate regarding these waters; and 2) whether the injured party was an employee of the party against whom the claim was made, as the Court regarded it to be a violation of due process to impose absolute liability on an employer unless a master-servant relationship in fact existed. ${ }^{103}$

This sort of inquiry might seem counterintuitive to those living in the modern administrative state. Observers assume that the authority granted to an administrative agency includes the authority to determine facts affecting whether the matter is within the agency's field of regulation, and moreover that anything more than deferential review of the great number of such determinations made each day would be highly inefficient. What brought the Crowell Court to reject such an approach? There are two major explanations. The first is that the Court was stricken by a bloody-minded "naïve realism," under which it believed that jurisdictional determinations were natural facts to be found rather than judgments to be made, and that each reviewing court must find these facts for itself. ${ }^{104}$ The second is that the Court

\footnotetext{
99. Crowell v. Benson, 285 U.S. 22, 54 (1932) (footnote omitted).

100. Jaffe, supra note 98, at 954-55. The first such case was Terry v. Huntington, 145 Eng. Rep. 557 (Ex. 1680), which involved a tax on "strong wines." When the petitioner claimed that his were actually low wines, judicial review was necessary to determine if the Commissioners of Excise had jurisdiction to levee the tax. Id. at 559.

101. Dickenson, supra note 31, at 1063, 1067.

102. 285 U.S. 22 (1932).

103. Dickenson, supra note 31, at 1057-58.

104. Id. at 1074-75.
} 
was responding to a perceived "legitimacy deficit" in the utilization of administrative authority and expressing a discomfort with the expansion of administrative power as an imposition on due process. ${ }^{105}$

These two rationales can be seen at work in one of the first cases to apply constitutional fact. In Ng Fung Ho v. White, ${ }^{106}$ Justice Brandeis, writing for the majority, justified the mandate of a "judicial trial" of "the claim of citizenship by a resident, so supported both before the immigration officer and upon petition for a writ of habeas corpus" ${ }^{107}$ on both jurisdictional fact and on due process grounds. The jurisdictional issue arose because "jurisdiction in the executive... exists only if the person arrested is an alien." ${ }^{108}$ The determination of this fact could not be left to the administrative agency because "where there is jurisdiction a finding of fact by the executive department is conclusive" unless there is a due process violation such as a denial of hearing or lack of evidence to support the agency's finding. ${ }^{109}$ The implication is that, where the right at stake is important enough, to allow the agency to have the last word on the central factual question would itself be a violation of due process, an implication made explicit in Brandeis's statement later in the decision:

To deport someone who so claims to be a citizen, obviously deprives him of liberty .... It may result also in loss of both property and life; or of all that makes life worth living. Against the danger of such deprivation without the sanction afforded by judicial proceedings, the Fifth Amendment affords protection in its guarantee of due process of law. The difference in security of judicial over administrative action has been adverted to by this court. ${ }^{110}$

Constitutional fact doctrine as laid out by Brandeis in $\mathrm{Ng}$ Fung Ho was a more limited principle than a doctrine based purely on jurisdictional fact would have been, as the opinion implied that jurisdictional

105. Monaghan, supra note 31, at 239 (noting that the court "may be required independently to find the relevant historical facts on the basis of its own record" because of "the "legitimacy deficit' inherent in administrative adjudication").

106. 259 U.S. 276 (1922).

107. Id. at 282 .

108. Id. at 284.

109. Id.

110. Id. at 284-85. The Court had earlier held that the Due Process Clause of the Fourteenth Amendment required the independent review of rate-setting actions by administrative agencies. Ohio Valley Water Co. v. Ben Avon Borough, 253 U.S. 287, 289-91 (1920) ("In all such cases [in which the administrative agency legislatively prescribed a rate schedule] ... the State must provide a fair opportunity for submitting that issue to a judicial tribunal for determination upon its own independent judgment ....."). 
facts required de novo review only when the threat to liberty was a significant one. ${ }^{111}$

As mentioned above, the Court's 1932 decision in Crowell v. Benson also mandated the review of jurisdictional facts based in the Constitution, citing $\mathrm{Ng}$ Fung $\mathrm{Ho}$ to the effect that due process is endangered when an administrative agency makes "the final determination of the existence of the facts upon which the enforcement of the constitutional rights of the citizen depend." ${ }^{112}$ Brandeis, however, dissented in Crowell. He rejected the entire concept of jurisdictional fact, as " $[\mathrm{t}]$ he power of Congress to provide by legislation for liability under certain circumstances subsumes the power to provide for the determination of the existence of those circumstances." majority's approach, Brandeis argued, the commissioner would not have final say over any fact to be determined before the question of liability itself. ${ }^{114}$

In a highly influential article, John Dickenson joined Brandeis's critique of jurisdictional fact, on the grounds that the doctrine of constitutional fact as articulated in Crowell had the potential to draw reviewing courts, and ultimately the Supreme Court, into the full-time business of factfinding. ${ }^{115}$ The resulting decisions would undermine administrative efficiency without serving any useful appellate end, as "being only decisions on facts, [these decisions] have small value or no value as guides in future cases." 116 Dickenson further complained that there was no way to determine the facts to which de novo review applied, since under the Crowell Court's definition of due process, "there is practically no issue going to the substantial merits of a con-

111. Jaffe, supra note 98, at 969 (arguing that not every jurisdictional fact must be determined judicially, but only those of greatest import).

112. Crowell v. Benson, 285 U.S. 22, 56 (1932). Crowell also dealt with other jurisdictional issues: whether the granting of such judicial power to an executive commissioner violated Article III or the Seventh Amendment. Id. at 37. While Crowell's holding on jurisdictional fact long ago lost relevance, these other issues remain active areas of Supreme Court jurisprudence. For a discussion of Crowell and its progeny in this regard, see Ellen E. Sward, Legislative Courts, Article III, and the Seventh Amendment, 77 N.C. L. REV. 1037 (1999) (analyzing the Court's decisions regarding the constitutionality of jury-less adjudications in legislative courts).

113. Crowell, 285 U.S. at 85 (Brandeis, J., dissenting).

114. Id. at 73-74 (Brandeis, J., dissenting).

115. Dickenson, supra note 31, at 1077 ("It would be ... disruptive of administrative processes, to hold that every fact-issue on which a claim of constitutional right can be made to depend becomes thereby entitled to a retrial on new evidence in a review proceeding at law.”).

116. Id. at 1074-75. 
troversy which if 'unreasonably' decided by an administrative tribunal cannot be made the basis of a . . constitutional right." 117

The potential in Crowell for the general de novo review of administrative findings was limited in St. Joseph Stock Yards Co. v. United States, ${ }^{118}$ in which the Court recognized the need to give deference to the findings of administrative agencies where these findings were based on the superior expertise of those agencies. ${ }^{119}$ Justice Brandeis concurred with the decision, reconciling his seemingly contradictory arguments in $\mathrm{Ng}$ Fung Ho and Crowell. While still rejecting jurisdictional fact, Justice Brandeis called for de novo review where "the right to liberty of person" was threatened. ${ }^{120}$ As St. Joseph was a takings case, Justice Brandeis concurred in the application of deferential review. ${ }^{121}$

After St. Joseph, jurisdictional fact review disappeared from American administrative law. Although the Supreme Court never explicitly overruled Crowell, deference to administrative decisions now extends beyond their findings of jurisdictional fact to their interpretations of their own enabling statutes. ${ }^{122}$ The de novo review of administrative findings of fact where fundamental rights are at issue is still occasionally applied, however. ${ }^{123}$ For example, Brandeis's standard was borne for a time by Justice Marshall, who invoked $\mathrm{Ng}$ Fung Ho in finding that the Immigration and Nationalization Act requires de

117. Id. at 1077. Louis Jaffe contends that Dickenson was mistaken in his contention that there was no limiting principle to the Crowell decision's application of constitutional fact. Jaffe, supra note 98, at 972-73. Professor Jaffe argues that the decision makes it clear that constitutional facts are only those facts which are of particular constitutional significance, and that the court assumes that these would be few in number. $I d$. at 972. Professor Jaffe assumes that the majority implicitly adopts the limiting principle of Brandeis in Ng Fung Ho. Id. at 972 n.66. Even if this is true, it is far from evident that a clear limiting principle can be constructed from a focus on the importance of the right at issue, as it is difficult to prioritize rights. This is the central point of the critiques of constitutional fact doctrine discussed infra notes 210-15 and accompanying text.

118. 298 U.S. 38 (1936).

119. Id. at 54 .

120. Id. at 77 (Brandeis, J., concurring).

121. Id. at 77-78 (Brandeis, J., concurring).

122. E.g., Chevron U.S.A. Inc. v. NRDC, 467 U.S. 837 (1984) (upholding the Environmental Protection Agency's interpretation of a portion of its enabling statute, the Clean Air Act).

123. Bernard Schwartz, Administrative LaW: A CASEbook 872 (1994) (explaining that some lower federal courts and state courts still apply the Ben Avon doctrine, which requires full review where a constitutional issue is raised). 
novo review when a resident who claims to be a citizen can supply some quantum of proof. ${ }^{124}$

2. "Procedural Liberty" Line. The same year that constitutional fact review in administrative law was largely quashed in St. Joseph, a new line of constitutional fact cases centering on Fourth and Fifth Amendment claims was initiated in Norris v. Alabama. ${ }^{125}$ In Norris, the Court reviewed an equal protection claim where blacks were excluded from a grand jury when a black person was on trial. ${ }^{126}$ Conceding that the inquiry into the cause of this exclusion was an issue of fact, the Court held:

That the question is one of fact does not relieve us of the duty to determine whether in truth a federal right has been denied. When a federal right has been specially set up and claimed in a state court, it is our province to inquire not merely whether it was denied in express terms but also whether it was denied in substance and effect. If this requires an examination of evidence, that examination must be made. Otherwise, review by this Court would fail of its purpose in safeguarding constitutional rights. Thus, whenever a conclusion of law of a state court as to a federal right and findings of fact are so intermingled that the latter control the former, it is incumbent upon us to analyze the facts in order that the appropriate enforcement of the federal right may be assured. ${ }^{127}$

Commentators have argued that Norris picked up and carried forth the concern for procedural liberty expressed in $\mathrm{Ng} \mathrm{Fung} \mathrm{Ho}$ and Crowell. ${ }^{128}$ However, the Norris Court also relied on an older principle to justify de novo fact review. The passage quoted above cited a 1912 case, Creswill v. Grand Lodge Knights of Pythias of Georgia, ${ }^{129}$ and a 1927 case, Fiske v. Kansas, ${ }^{130}$ for the proposition that

124. Agosto v. INS, 436 U.S. 748, 753 (1978). Justice Marshall also argued that constitutional fact doctrine should be applied to a magistrate's findings in a suppression hearing. United States v. Raddatz, 447 U.S. 667, 712 (1980) (Marshall, J., dissenting).

125. 294 U.S. 587 (1935).

126. Id. at 596 .

127. Id. at 589-90.

128. E.g., Monaghan, supra note 31, at 260-62 ("While commentators focused on Crowell's decline in the field of administrative law, they began to notice that constitutional fact review had become the operative measure of the Supreme Court's general appellate jurisdiction."); Strong, supra note 25, at 245 ("Neither Ben Avon, Crowell nor Fung Ho is anywhere cited in the opinion, but there is no mistaking that the degree of independent judicial review surviving from them constitutes the decision's inarticulated major premise.").

129. 225 U.S. $246(1912)$.

130. 274 U.S. 380 (1927). 
this Court will review the finding of facts by a State court where a federal right has been denied as the result of a finding shown by the record to be without evidence to support it; or where a conclusion of law as to a Federal right and a finding of fact are so intermingled as to make it necessary, in order to pass upon the Federal question, to analyze the facts. ${ }^{131}$

Both Creswill and Fiske were decided on substantial-evidence grounds, but the latter principle, that de novo fact review is appropriate where the issue is a mixed question of fact and law concerning a constitutional right, remained dormant and available for the Norris Court to pick up in 1935.

The Norris Court did not make a new inquiry into historical events or a new judgment about the credibility of the witnesses. It did, however, independently determine what weight to give to the facts in the record. The Court weighed the uncontroverted fact that there were no blacks on the jury rolls, and the fact that no black person had served on a jury in the county in question in living memory, against the claims of county officials that no racial motivation lay behind these omissions, and concluded that the evidence supported the factual conclusion that blacks had been excluded from juries because of their race. ${ }^{132}$

In later cases in the Norris line, the Court would continue to utilize this approach of accepting the trial court's findings on the underlying facts while making its own determination of the significance of those facts. ${ }^{133}$ In Watts $v$. Indiana, ${ }^{134}$ for example, Justice Frankfurter wrote that "issue of fact' is a coat of many colors. It does not cover a conclusion drawn from uncontroverted happenings, when that conclusion incorporates standards of conduct or criteria for judgment which in themselves are decisive of constitutional rights."

The Supreme Court justified plenary review of such mixed questions of fact on the principle that the appellate courts should control the development of the law. Where the rule of law and the facts of the

131. Id. at 385-86. In Creswill, the Court made the same point: "[W]here a Federal right has been denied as the result of a finding of fact which it is contended there was no evidence whatever to support and the evidence is in the record the resulting question of law is open for decision." 225 U.S. at 261.

132. Norris, 294 U.S. at 590-93.

133. The line includes Ashe v. Swenson, 397 U.S. 436 (1970) (reviewing a collateral estoppel/double jeopardy determination), Payne v. Arkansas, 356 U.S. 560 (1958) (reviewing the voluntariness of a confession), and Watts v. Indiana, 338 U.S. 49 (1949) (same).

134. 338 U.S. 49 (1949).

135. Id. at 51 . 
case are intermingled, the rule of law is developed through its application. On this basis, plenary review is inappropriate where, as Dickenson argued in his critique of administrative constitutional fact, decisions "have small value or no value as guides to future cases." 136 The Court therefore refused to apply independent review to issues, such as a unitary business question in a tax case, where the "legal principles defining the constitutional limits ... are now well established" and the record is too complex to be fully reconstructed by an appellate court. ${ }^{137}$

This is not to say that the Court was merely concerned with law declaration in these cases, or that effective declaration was always possible. For example, in the field of review Watts initiated, the voluntariness of confessions, the Court was drawn into a series of highly fact-specific inquiries that did not result in clear rules such that the Court could ever leave the field. The Court finally escaped this burden of review only by vastly simplifying voluntariness down to the technicalities of Escobedo and Miranda. ${ }^{138}$

It can be argued that because the application of plenary review in the procedural line of cases is primarily justified by the mixed nature of the questions addressed, these cases are not about constitutional facts at all, but are rather examples of a traditional doctrine under which all mixed questions of fact and law are subject to independent review. Steven Childress, for example, has argued that there has been a general "over-labeling" of such cases as constitutional fact cases. ${ }^{139}$ All mixed questions of fact and law are in theory subject to plenary review, ${ }^{140}$ but the Supreme Court in practice applies deferential re-

136. Dickenson, supra note 31, at 1075.

137. Container Corp. of Am. v. Franchise Tax Bd., 463 U.S. 159, 176 (1983). The Court may have also been unsympathetic to applying constitutional fact review to this case because individual liberty was not at issue.

138. Frank R. Strong, Dilemmic Aspects of the Doctrine of "Constitutional Fact," 47 N.C. L. REV. 311, 327 (1969); Strong, supra note 25, at 281-82; see also Keith R. Dolliver, Comment, Voluntariness of Confessions in Habeas Corpus Proceedings: The Proper Standard for Appellate Review, 57 U. CHI. L. REV. 141, 145 (1990) ("Miranda itself can be understood as an effort by the Court to develop a clear rule that would free it from case-by-case determinations of voluntariness."). The Court's recent decision to uphold Miranda in Dickenson v. United States, 530 U.S. 428 (2000), indicates that the Court continues in its desire to avoid the issue as much as possible.

139. Childress, supra note 26 , at 1240 ("To the extent that these cases merely restate the oftcited rule that legal conclusions or mixed law-fact questions fall outside complete fact-finding protections, such as the clearly erroneous standard of Federal Rule 52(a), they are not revolutionary or particularly necessary as a separate exception.").

140. Pullman-Standard v. Swint, 456 U.S. 273, 289 (1982) (noting that mixed questions of fact and law are subject to appellate review). 
view where constitutional rights are not implicated. ${ }^{141}$ This indicates that even though the mixed nature of the questions involved is the explicit and primary reason the Court has applied plenary review in these cases, the constitutional implications of the facts involved are an important, if sometimes unstated, motivation for the application of this standard of review.

3. "Substantive Liberty" Line. The area of the law to which the doctrine of constitutional fact has been most consistently applied is the First Amendment. Beginning with Pennekamp v. Florida, ${ }^{142}$ the Supreme Court has consistently held that reviewing courts must "examine for [them]selves the statements in issue and the circumstances under which they were made" to see whether the statements represent protected speech. ${ }^{143}$ As with the proceduralliberty line of cases, in the substantive liberty cases "it is the findings of the state courts on undisputed facts or the undisputed facts themselves which ordinarily furnish the basis for [the Court's] appraisal of claimed violations of constitutional rights." ${ }^{144}$ The Court does not conduct a new trial of the underlying facts, but it will weigh these facts independently.

Unlike review in the procedural-liberty line, however, the underlying motive for review in First Amendment cases has often been more about the protection of rights in individual cases than about guiding the development of the rule through controlling its application in a mixed question of fact and law. ${ }^{145}$ Nowhere has this been clearer than in the area of obscenity review. In Jacobellis v. Ohio, ${ }^{146}$ the Court, citing Watts, Norris, Pennekamp, Ng Fung Ho, and Crowell, held that reviewing courts must make an independent review of

\footnotetext{
141. Jeffrey Grybowski, Note, The Appellate Role in Ensuring Justice in Fourth Amendment Controversies: Ornelas v. United States, 75 N.C. L. REV. 1819, 1843-44 (1997) (citing, among other cases, Cooter \& Gell v. Hartmax Corp., 496 U.S. 384 (1990) (applying deferential review to a lower court's determination that an attorney held a "reasonable belief" that the suit he brought was not frivolous under Rule 11 of the Federal Rules of Civil Procedure); and Commissioner v. Duberstein, 363 U.S. 278, 290-91 (1960) (reviewing with deference the holding of a lower court that a transaction constituted a "gift" for tax purposes)).

142. 328 U.S. 331 (1946) (concerning whether a newspaper's criticism of a court constituted a "clear and present danger" such that the criticism could be punished as contempt of court).

143. Id. at 335.

144. Id. at 345 .

145. Childress, supra note 26, at 1235 (arguing that constitutional fact doctrine in First Amendment cases "finds its source not in law-declaration but rather in a separate protectionist role placed on the courts under a heightened due process standard").

146. 378 U.S. 184 (1964).
} 
allegedly obscene material. ${ }^{147}$ The Court admitted that it could have applied a sufficient-evidence standard, but held that its duty to uphold due process forced it to shoulder "a difficult, unpleasant, and recurring task." ${ }^{\text {148 }}$ Chief Justice Warren dissented, calling for a rule of reason that would free the Supreme Court from "sitting as the Super Censor of all the obscenity purveyed throughout the nation." ${ }^{149}$

The Court was not oblivious of the need to draw lines by which to guide lower courts trying and reviewing obscenity cases. But the standard for finding obscenity-whether "to the average person, applying contemporary community standards, the dominant theme of the material taken as a whole appeals to prurient interest" ${ }^{\text {"150 }}$ - inherently resisted clarification by a national court. Moreover, any definitions that were established could find support from no more than a plurality on the Court, keeping the field open for a changing array of coalitions and approaches. Finally, in Miller v. California, ${ }^{151}$ Chief Justice Burger wrote for a clearly frustrated majority of six in trying to put an end to "the "intractable obscenity problem" by drawing a bright line limiting obscenity to hard-core pornography that contains the depiction or description of sexual conduct or genitalia. ${ }^{152}$ It cannot be said that this rule emerged from the process of applying the previous obscenity standard; it was more an attempt to limit the Court's involvement in an arena in which application had utterly failed to produce a clearer rule. ${ }^{153}$

147. Id. at $187-88$

148. Id. at 187.

149. Id. at 203 (Warren, C.J., dissenting).

150. Roth v. United States, 354 U.S. 476, 489 (1957).

151. 413 U.S. 15 (1973).

152. Id. at 16, 24 (quoting Interstate Circuit, Inc. v. Dallas, 390 U.S. 676, 704 (1968) (Harlan, J., concurring and dissenting)).

153. Even then, Justice Douglas was unimpressed by the majority's effort at law declaration, arguing that the only relief from the "I know it when I see it" model of review was for the courts to refrain from regulating obscenity at all. Id. at 41 (Douglas, J., dissenting). The Miller decision largely enabled the Court to declare victory and leave the field, but obscenity cases still occasionally would be granted certiorari. In Jenkins v. Georgia, 418 U.S. 153 (1974), for example, the Court held that the film Carnal Knowledge (Metro-Goldwyn-Meyer 1971) was clearly not the sort of "hard core" material the Miller rule described. Writing for the majority, Justice Rehnquist granted that the Court would protect First Amendment rights through independent review, but expressed frustration that it should have to in cases such as this. Jenkins, 418 U.S. at 160-61. For a recent case attempting to clarify further which aspects of the Miller test are subject to independent review, see United States v. Various Articles of Merchandise, 230 F.3d 649, 653 (3d Cir. 2000), which held that the determination of whether the work "appeals to the prurient interest" under "contemporary community standards" is to be reviewed for clear error, while the determination of whether the work depicts sexual conduct "in a patently offensive way" and 
The substantive line of constitutional fact review took on new strength with Bose Corp. v. Consumers Union of United States, Inc. ${ }^{154}$ which has been interpreted by lower courts to require plenary review in all cases involving First Amendment issues, even where the issue is freedom of religion rather than freedom of speech. ${ }^{155}$ As mentioned above, ${ }^{156}$ the Bose Court ruled that despite Federal Rule of Civil Procedure 52(a), which requires that findings of facts be reviewed on a clear-error standard, reviewing courts must independently review findings of actual malice in defamation suits. The principle of independent review in defamation suits comes from New York Times Co. v. Sullivan, ${ }^{157}$ in which the Court held that "[w]e must 'make an independent examination of the whole record,' so as to assure ourselves that the judgment does not constitute a forbidden intrusion on the field of free expression." 158

The Sullivan Court does not express much concern about law declaration in this passage. The Bose Court, however, justified plenary review of actual-malice determinations on both the nature of the question and the nature of the right, asserting that "the content of the rule is not revealed simply by its literal text, but rather is given meaning through the evolutionary process of common-law adjudication ... [and] the constitutional values protected by the rule make it imperative that judges ... make sure that it is correctly applied." ${ }^{159}$

whether the work has serious "literary, artistic, political or scientific value" is to be made de novo.

154. 466 U.S. 485 (1984).

155. E.g., Doe v. Small, 934 F.2d 743, 752 (7th Cir. 1991) (holding that the question of whether the average person would regard a state action as endorsing a particular religion is a constitutional fact); New Life Baptist Church Acad. v. Town of East Longmeadow, 885 F.2d 940, 941-42 (1st Cir. 1989) (holding that the Bose standard applies in a freedom of religion case); Price v. Brittain, 874 F.2d 252, 255, 257-58 (5th Cir. 1989) (noting, in a case reviewing whether statements made by a dismissed employee were protected speech or "rumor-mongering," that where the issue is the First Amendment, the court must make an independent review of the record).

156. See supra notes $48-54$ and accompanying text.

157. 376 U.S. 254 (1964).

158. Id. at 285 (citations omitted).

159. Bose, 466 U.S. at 501-02 (1984). For examples of the evolutionary process of the common law, the Bose Court looked to the jurisprudence of fighting words and obscenity, where the "Court has regularly conducted an independent review of the record both to be sure that the speech in question actually falls within the unprotected category and to confine the perimeters of any unprotected category within acceptably narrow limits in an effort to ensure that protected expression will not be inhibited." Id. at 505. The Court quoted Justice Harlan in Roth v. United States to support this proposition: "Since [the standards of obscenity] do not readily lend themselves to generalized definitions, the constitutional problem in the last analysis becomes one of particularized judgments which appellate courts must make for themselves." Id. at 506 n.25 (quoting Roth v. United States, 354 U.S. 476, 497 (1957) (Harlan, J., concurring and dis- 
Despite the Court's appeal to its roles both as a protector against specific threats to the individual liberty at issue in the case and as the shepherd of the law through its application, commentators on the case have argued that the Bose Court was truly concerned with only the immediate issue of rights protection. ${ }^{160}$ This argument is supported by the fact that once the Bose Court justified applying plenary review to the question of actual malice, it determined the factual question with little or no attempt to extract rules or principles of application from its efforts.

4. Distrust of the Finder of Fact. Before moving on to the postBose development of constitutional fact, it is useful to reflect on the third justification for applying plenary review to issues of constitutional fact. The first two, the need to protect an individual right through appellate review and the need for the appellate courts to supervise the development of rules where those rules emerge only through the process of determining mixed questions of fact and law, are clear enough in the case law and have been discussed above. Distrust of the factfinder is often also a reason, if unstated, to conduct plenary review. Such distrust logically must exist where the primary justification for nondeferential review is the protection of a right, for there would be no need for such a standard if the trial court were trusted to protect the right itself. There is no corresponding logical necessity that such distrust exist where plenary review is justified by the nature of the question, because such review can be premised on the need for consistency in the interpretation and declaration of the law rather than on any imputation of incompetence or bias on the part of the trial court. ${ }^{161}$

There is often just such an imputation, however, even in the cases that justify review primarily on the nature of the question. It is

senting)). Interestingly, this passage seems to support the idea that independent review is necessary despite the impossibility of law declaration in the obscenity field, rather than because of the need to declare law.

160. E.g., Childress, supra note 26, at 1256-62 (analyzing the impact of the Bose decision); Lee Levine, Judge and Jury in the Law of Defamation: Putting the Horse Behind the Cart, 35 AM. U. L. REV. 3, 35 (1985) ("[T]he constitutional values protected by the rule [r]eceived the court's most extensive attention and ultimately constituted the ratio decidendi for the Bose decision.").

161. See Ornelas v. United States, 517 U.S. 690, 697 (1996) (applying independent review because deference to trial courts' determinations of probable cause would allow for different results in similar cases, and "[s]uch varied results would be inconsistent with the idea of a unitary system of law"); Alexander, supra note 22, at 185 (describing the desire for uniformity of the law as a motivating factor in judicial review). 
argued that the trial court's findings should be treated deferentially unless the appellate court has some special competence, or the trial court some special bias, in making the sort of finding at issue. For example, in his dissent to Bose, Justice Rehnquist, joined by Justice O'Connor, argued strongly that the finding of actual malice is the determination of the actual state of mind of the alleged defamer, and therefore involves historical and credibility determinations that are in the special competence of the jury. ${ }^{162}$ Justice Rehnquist contended that constitutional fact doctrine should be limited to determinations such as those in obscenity or fighting-words cases, where the issue is not historical fact but what the reaction of a "reasonable person" to speech would be. ${ }^{163}$ Justice Rehnquist suggested that an appellate court is at least as competent as any other judicial actor to make this determination. ${ }^{164}$

With regard to this last point, it is equally plausible to say that the trier of fact is in a better position to know the full circumstances of the case and therefore to be able to put itself in the shoes of the "reasonable person" in that situation. Moreover, many reasonableness standards are supposed to reflect the reason of a particular community, making it likely that a local judge or especially a jury is more competent than the Supreme Court to make such findings.

However, Justice Rehnquist's point may be less that Supreme Court Justices are better able to channel the spirit of the reasonable person than that the reasonable person standard is a standard of law, even when left with the jury, and so it is ultimately within the purview of the appellate courts. This point recapitulates an argument made at the turn of the century in the debate over whether negligence is a question of law or fact. The major protagonists in this debate were James Thayer, who argued that a finding of negligence was a finding of fact because it was not a choice between precedentially established rules, ${ }^{165}$ and Oliver Wendell Holmes, who argued that a finding of negligence was one of law because it established a standard of conduct, even if that standard was good for one case only. ${ }^{166}$ This dispute between Thayer and Holmes can be seen as being about whether the determination of negligence is a question of is or a question of ought.

\footnotetext{
162. Bose, 466 U.S. at 515-17 (Rehnquist, J. dissenting).

163. Id. (Rehnquist, J., dissenting).

164. Id. (Rehnquist, J., dissenting).

165. James B. Thayer, "Law and Fact” in Jury Trials, 4 HARV. L. REV. 147, 154 (1890).

166. Oliver WeNDEll Holmes, THE COMMON LAW 122-24 (1881); Holmes, supra note 5, at $458-59$ (1899).
} 
Thayer argued that it is a question of $i s$, an appeal to general experience on how the prudent man would act in a given set of circumstances. ${ }^{167}$

In the 1920's, Francis Bohlen countered:

Were the "reasonable man" identical with the average man and were the question what the average conduct of mankind under similar circumstances is, the question would be purely one of factof what is or exists .... But the "reasonable man" is not the average man. He is an ideal creature, expressing public opinion declared by its accredited spokesman, whether court or jury, as to what ought to be due under the circumstances... . The factor controlling the judgment of the defendant's conduct is not what is, but what ought to be. ${ }^{168}$

Like Holmes, Bohlen believed that such a standard, which determines rights and responsibilities, even if only in one case at a time, was closer to law than to fact. ${ }^{169}$ However, just because to rule on what the reasonable man would find is to declare the law, it does not mean that this project has to be undertaken by a judge, as the allocation of the negligence determination to the jury shows. Justice Rehnquist's Bose dissent tells us when we should leave decisions in the hands of the jury - when credibility is at issue-but identifying a question as one of law does not in itself say why we should take the final judgment of that question away from the trier of fact.

Interestingly, James Thayer also had much to say about the process by which judges take questions of fact away from juries. Professor Thayer described several strategies by which judges have usurped the role of jury as factfinder. ${ }^{170}$ One such strategy is to fix the definitions of legal terms. Once a term like "malice," "false pretenses," "fraud," or "insanity" is attached to a question of fact, judges may take over the factfinding process in the name of giving definition to

167. James B. Thayer, A Preliminary Treatise On Evidence at the Common Law 227-28 (1898).

168. BOHLEN, supra note 5, at 603-04.

169. Morris, supra note 5, at 1315-16 (recognizing that Bohlen thought that a verdict determining whether defendant acted as a reasonably prudent man was a decision relating more close to law than fact); see also Thompson v. Keohane, 516 U.S. 99, 113 n.13 (1995) (arguing that what jurors do in negligence cases is much like what judges do, except that it cannot be reduced to a definite rule).

170. Thayer, supra note 165, at 162, 166 (discussing judges' use of demurrers upon evidence and rules of presumption). 
the term. ${ }^{171}$ Martin Louis has noted that through their classifying power, courts can classify as mixed or legal issues questions that are otherwise indistinguishable from fact. ${ }^{172}$ But whereas once courts reclassified because they did not trust juries to decide certain questions rationally, in recent decades courts have done so more out of a wish to have the final say on "questions of law." Supreme Court has used its power to reclassify questions of fact as questions of constitutional fact to ensure that it has the final word. The Court has taken what might otherwise be seen as descriptions of historical fact, like "reasonable suspicion" or "actual malice," and by calling them legal standards has made it necessary for appellate courts to conduct plenary review over their application.

\section{Post-Bose Developments: The Fusing of Procedural and Substantive Lines}

The Bose decision evoked considerable criticism, much of it concerned with the prospect that the Court was establishing a doctrine of independent review that could not be limited to defamation suits. ${ }^{174}$ Like Professor Dickenson before them, critics like Professor Monaghan worried that an overly expansive constitutional fact doctrine would either overwhelm the federal docket or force appellate courts to withdraw from independent review of facts altogether. As one commentator sympathetic to the need for independent judgment "on facts that are controlling of constitutionality" pointed out, constitutional fact review can lead to a quagmire of case-by-case determinations when combined with the sort of constitutional standards "that are the product of judicial balancing of individual right and public interest" appearing in "lines especially demanding of factual judgment for their effective enforcement." ${ }^{175}$ As we have seen, such quagmires

171. Id. at 161-62. Of course, many questions of ultimate fact have such terms attached to them, including negligence. Again, it would seem that the existence of such a term does not in itself necessitate the reallocation of a question from jury to judge, absent a policy motivation to do so.

172. Louis, supra note 24 , at 1027-28. Louis suggests that the construction of writings is such an instance.

173. Id. at 1028 n. 260 .

174. E.g., George C. Christie, Judicial Review of Findings of Fact, 87 Nw. U. L. REV. 14, 39 (1992) (focusing on the determination of how the judicial question should be addressed to identify which decision-maker should decide the question); Monaghan, supra note 31, at 264, 269-70 (noting that it is difficult to believe that all First Amendment rules suffer from the defects of rules in defamation cases).

175. Strong, supra note 25, at 279, 281. 
developed from the Court's involvement in determinations of the voluntariness of confessions, from which it extricated itself only through the somewhat mechanical rules of Escobedo and Miranda, ${ }^{176}$ and in the Court's review of obscenity findings, which required the Justices personally to pass on the speech value of the material at issue in a "constitutional disaster area" ${ }^{177}$ that the Court could only escape by drawing a (somewhat) bright line in Miller v. California. ${ }^{178}$

To guard against such difficulties, Henry Monaghan suggested that constitutional fact review should be limited to cases in which there was either the need and the possibility for a case-by-case development of the law, or a danger of a systematic bias on the part of the trier of fact. ${ }^{179} \mathrm{He}$ specifically rejected any reliance on the nature of the right as a guide to application, arguing that the source and limits of distinctions such as Brandeis's prioritization of personal rights were too unclear. ${ }^{180}$ Citing Monaghan, ${ }^{181}$ the Court soon moved to redefine constitutional fact doctrine so that both the substantive and procedural lines were justified primarily on the nature of the question at issue rather than the nature of the right under threat. ${ }^{182}$

The central case in this redefinition was Miller v. Fenton, ${ }^{183}$ in which the Court reaffirmed that state findings on the voluntariness of confessions were subject to plenary federal review, despite 28 U.S.C. $\S 2254$ (d)'s requirement that findings of fact be reviewed for sufficient evidence. ${ }^{184}$ Writing for the majority, Justice O'Connor held that nondeferential review should be applied where 1) as with First Amendment cases, the law is given meaning through its application to par-

\footnotetext{
176. Id. at 281-82.

177. Id. at 281.

178. Such concerns were bound to find resonance with a Court so concerned about docket pressure and judicial efficiency that Justice Rehnquist at one time argued that we have "a seeming compulsion to make sure that the result reached in any case is the correct one," and that given the cost to lawyers' time, finality, and the speed of disposition, "perhaps, speaking of the federal system, the time has come to abolish appeal as a matter of right from the district courts to the courts of appeals." William H. Rehnquist, Address Before the 75th Anniversary of the University of Florida College of Law and the Dedication of Bruton-Geer Hall (Sept. 15, 1984), in L.A. DAILY J., Sept. 21, 1984, at 4 (excerpting speech in which Rehnquist expresses concerns about the balance between efficiency and accuracy).

179. Monaghan, supra note 31, at 271.

180. Id. at 265-66.

181. Monaghan, supra note 31, at 237 (cited in Miller v. Fenton, 474 U.S. 104, 114 (1985)).

182. CHILDRESS \& DAVIS, supra note $17, \S 2.19$ (arguing that in recent years the Court has interpreted Bose in such a way as to align it with traditional mixed-question doctrine, focusing on legal reasoning rather than constitutional ramifications).

183. 474 U.S. 104 (1985).

184. Id. at 118 .
} 
ticular circumstances; or 2) review compensates for perceived bias by the trier of fact. ${ }^{185}$ Plenary review is contraindicated where the finding is primarily based on the determination of the credibility of witnesses. ${ }^{186}$ This test was framed as an issue of judicial competence, for "the fact/law distinction at times has turned on a determination that ... one judicial actor is better positioned than another to decide the issue in question." ${ }^{187}$

In the course of this discussion, Justice O'Connor primarily cited Monaghan, Bose, and Justice Rehnquist's dissent to Bose, implying that the test in Miller was equally applicable to the substantive and procedural lines. In subsequent cases considering whether to apply plenary review to questions of fact, the Court has followed Miller in its analysis, focusing on the nature of the question rather than the nature of the right, whether the case has involved a procedural claim ${ }^{188}$ or a speech issue. ${ }^{189}$ The Miller approach has found unanimous acceptance on the Court. In Ornelas v. United States, ${ }^{190}$ for example, all nine of the Justices agreed that the test for whether to apply plenary review hinged on whether the rule at issue developed through application and on the respective competence of the trial and reviewing court. ${ }^{191}$

The Court also has interpreted its decision in Bose to be fully compatible with deference to the trier of fact's credibility determinations. In Harte-Hanks Communications, Inc. v. Connaughton, ${ }^{192}$ the Court held that its rejection in Bose of the jury's determination that the writer of the article in question, who unconvincingly denied that he had made any mistakes in his article, acted with actual malice did not entail a rejection of the jury's finding that the writer was not a

\footnotetext{
185. Id. at $116-17$.

186. Id. at 114 .

187. Id.

188. E.g., Hernandez v. New York, 500 U.S. 352, 367-69 (1991) (rejecting the application of plenary review to a Batson claim where the issue is distinguishable from Bose, Miller, and Norris).

189. E.g., Hurley v. Irish-American Gay, Lesbian \& Bisexual Group, 515 U.S. 557, 567 (1995) (applying plenary review to a question of whether the application of a state law in which parade sponsors were required to include the group in its parade was a violation of the sponsors' speech rights).

190. 517 U.S. 690 (1996).

191. Id. at 699. The case was an 8-to-1 decision. Justice Scalia agreed on the "essentially practical" considerations in the majority's approach, but disagreed on their application of these considerations. Id. at 700-03 (Scalia, J., dissenting).

192. 491 U.S. 657 (1989).
} 
credible witness. ${ }^{193}$ The Court accepted that he was not credible, but drew a different inference from this determination: that the writer gave self-serving testimony on the stand, not that he acted with malice when writing the article. ${ }^{194}$

With credibility thus defined in a binary matter-the Court must accept the jury's determination that a witness is a liar, but it need not necessarily accept the jury's determination of about what the witness is a liar-the decision in Bose is fully compatible with the "twotiered" approach taken in recent procedural-liberty cases, in which the Court accepts the state court's determination of the underlying historical facts, but makes its own findings on what import to grant these facts. ${ }^{195}$

\section{CRITIQUe OF THE CURRENT DOCTRINE OF CONSTITUTIONAL FACT}

\section{A. Effectiveness in Practice}

As has been described above, the major concern with constitutional fact doctrine is that if it is defined too expansively, it will overwhelm the docket of the federal appellate courts. One possible solution to this problem, available at least to the Supreme Court, is to use the discretion of certiorari to refuse to engage in plenary review. But this puts the Court in the position of ignoring "constitutionally offensive results"196 and does nothing to lessen the docket pressures on the courts of appeals. Another solution is to "fashion new, more detailed rules of substantive law, narrowing the discretionary scope of the trial-level determination and helping to characterize the particular results as clearly right or wrong." 197 This was the path chosen by the Court in its efforts to pull itself out of the morass of plenary fact review of obscenity and the voluntariness of confessions. The problem with this approach is that the rules created thereby can be formalistic and rigid.

193. Id. at 689 n.35.

194. Id.

195. See supra notes $132-35$ and accompanying text.

196. Louis, supra note 24, at 1038.

197. Id. at 1037 .

198. Id. at 1038 . 
The Court's current doctrine for applying constitutional fact review, as laid out in Miller v. Fenton, ${ }^{199}$ is an attempt to allow for plenary review while limiting its application to situations where law declaration is actually possible. If one were to judge the success of this solution from the Court's own sense of comfort in expanding the application of constitutional fact, one would have to say that it has been largely successful. In the 1990s, the Court has been willing in Thompson $v$. Keohane ${ }^{200}$ to hold that the determination of whether a suspect is in custody for the purposes of Miranda is a mixed question subject to independent federal review, and in Ornelas v. United States ${ }^{201}$ to hold that determinations of "reasonable suspicion" and "probable cause" were subject to independent review. And the Court has not felt it necessary to correct the impression on the part of several courts of appeals that all First Amendment questions are subject to plenary review. ${ }^{202}$

Whether the focus on the mixed nature of the question announced by Miller is an effective guide to lower courts is less certain, in part because there are relatively few cases that consider whether to apply plenary review as a matter of first impression. Tolbert v. Page $e^{203}$ and Mahaffey v. Page ${ }^{204}$ described at the beginning of this Note, ${ }^{205}$ are somewhat unusual in that these decisions include extensive discussions of the proper standard of review. Other cases do little more than declare that the matter at hand is ${ }^{206}$ or is not $^{207}$ a constitutional fact. It is interesting to note that Tolbert, in rejecting plenary review of the first stage of the Batson test, follows Miller closely, indicating that Miller is a useful tool for those who would restrict the application of plenary review. The Tolbert court found that the determination of whether there is a prima facie case of discrimination in the use of a

199. See supra notes 184-91 and accompanying text.

200. 516 U.S. 99, 112 (1995).

201. 517 U.S. 690, 691 (1996).

202. See supra note 155 and accompanying text.

203. 182 F.3d 677 (9th Cir. 1999) (en banc).

204. 162 F.3d 481 (7th Cir. 1998).

205. See supra notes 3-16 and accompanying text.

206. E.g., Continental Trend Res., Inc. v. Oxy U.S.A. Inc., 101 F.3d 634, 642-43 (10th Cir. 1996) (holding that whether a punitive-damage award is unconstitutionally excessive under $B M W$ v. Gore is a question of constitutional fact); Equal. Found. v. City of Cincinnati, 54 F.3d 261, 265 (6th Cir. 1995) (holding that whether homosexuals are a quasi-suspect class is a constitutional fact).

207. E.g., Quezada v. County of Bernalillo, 944 F.2d 710, 715-16 (10th Cir. 1991) (holding that the question of whether a police officer has used excessive force in violation of $\S 1983$ is not a constitutional fact). 
peremptory challenge is too tied to case-specific determinations of credibility to lend itself to the development of a rule through application, and that the trial court is in the best position to make such determinations. ${ }^{208}$ The Mahaffey court, on the other hand, in holding that plenary review does apply to the same question, had to veer from the Miller approach. The court did find that fact patterns in Batson claims will reoccur, so that independent review can provide guidance in future cases, but based its decision primarily on the heightened threat to the individual rights of the defendant in the case. ${ }^{209}$

\section{B. The Nature of the Question as an Incomplete Limit}

The limiting factor of the Miller approach to the scope of application of constitutional fact review is based on the assumption that instances where rules governing constitutional rights are developed through application are identifiable and limited in number. However, this view assumes that questions are by nature mixed or unmixed and ignores that courts themselves play a large role in how a question is categorized and whether a rule can be said to be determined through pure law declaration or through application.

What are mixed questions of law and fact anyway? Walter Cook, writing in 1936 when the distinction between statements of fact and conclusions of law was still central to pleading procedures, noted that pleadings were full of terms that were both statements of fact and conclusions of law. ${ }^{210}$ Cook gives the example of a statement that a plaintiff is "lawfully possessed" of something as a statement about both factual events and legal consequence. ${ }^{211}$ Clarence Morris provided an even clearer example by posing the question, "Are they married?" Morris had a clear definition of law and of fact"[p]ropositions of fact are descriptive, conclusions of law are dispositive " 212 - but noted that the question above is both a question of fact and of law. To answer it, one may require either the probative fact that X saw the ceremony with his own eyes, or the application of the legal definition of marriage to the circumstances of the ceremony. ${ }^{213}$

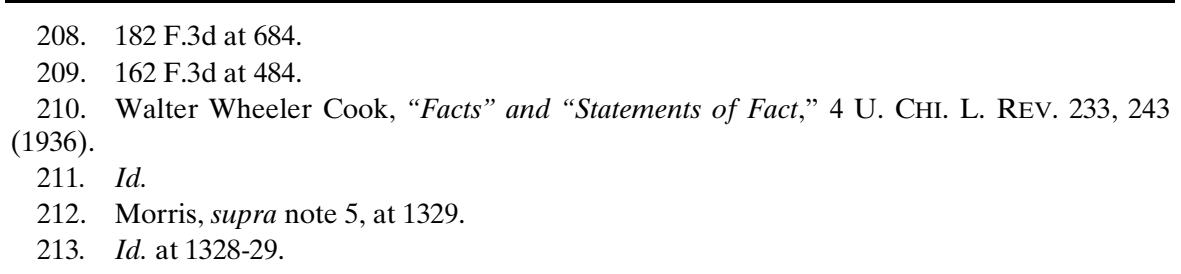


A very wide range of questions could similarly have both factual and legal elements, but Morris further recognized that the sort of answer required in any one case depends on the function the question plays in that case, not on the nature of the question itself. Morris noted that when parties dispute only facts, it is because they have agreed, tacitly, on the acceptability of certain rules of law. When they dispute only questions of law, it is because they have agreed, tacitly, on the facts. ${ }^{214}$ For example, if the question at issue is whether D conducted an illegal lottery, it is a question both of fact and law. But if the legal definition of lottery and the scope of the law is clear, it is primarily a question of fact. The dispositive element may not even be noticed. ${ }^{215}$

This raises this possibility that many issues were at one time mixed questions of fact or law but as one element or another became settled, they became more purely either issues of fact or of law. As we have seen ${ }^{216}$ the process can work in both directions, and issues of fact or law can be recategorized as mixed. Questions that have become settled instances of fact determination, such as obscenity or probable cause, can be recategorized as being more about determining rules of law. Although under the test of Miller v. Fenton it may take more logical gymnastics to make a question of fact into a question of constitutional fact, especially in comparison to Brandeis's call in $\mathrm{Ng}$ Fung $H o$ for plenary review whenever a threat to individual liberty exists, the extra effort is required because several steps are necessary to reframe the question, not because the inherent nature of questions themselves resists reframing. ${ }^{217}$

Take the review of the first step of a Batson claim, for example. ${ }^{218}$ By calling the question a "prima facie" determination, and by naming the claim as a whole after a Supreme Court case, the Court makes it clear to the legal reader that the issue is at least partly one of law. Moreover, the constitutional import of the question is clear, as it in-

\footnotetext{
214. Id. at 1305 n.4.

215. Id. at 1330

216. See supra notes $139-41$ and accompanying text.

217. On the other hand, the focus on the nature of the question may be inherently more conservative than a focus on the nature of the right, because when it is determined that a right is in need of special appellate protection, it is very hard to explain why similar rights do not deserve the same protections, creating the risk that the application of constitutional fact review, if applied consistently, will spread metonymically to all rights. A focus on the question, on the other hand, even if it involves the recategorization of that question, looks at the structure of each question in turn, and so is at least a more evolutionary process.

218. See supra note 4.
} 
volves both the Seventh and Fourteenth Amendments. ${ }^{219}$ But even here, a court following the Miller test must find that the appellate courts are in as good or better a position as the trial court to weigh the legal effect of the facts in the case, and that the issue is one that lends itself to the generalization of a rule from application, before constitutional fact review can be appropriately applied. ${ }^{220}$ Whether any particular issue satisfies this test, the fact that finding that it does must be so justified at least imposes an additional burden on a court seeking to expand constitutional fact review. This is one explanation for why the Tolbert court, applying the Miller test strictly, did not rule that constitutional fact review applied to the first step of the Batson test, ${ }^{221}$ while the Mahaffey court, which did not follow Miller strictly, did expand the scope of application of constitutional fact review. ${ }^{222}$

Another explanation is, of course, that courts must be motivated to expand the scope of application of constitutional fact review. If, as has been postulated in this part, there is some doubt as to whether questions are ever inherently ones of fact, law, or mixed questions of fact and law, the determination of which questions receive such treatment would seem to continue to greatly depend on the other two rationales behind constitutional review-distrust for the finder of fact and a perceived need to protect a right. The current approach to constitutional fact gives these factors a less formal place in the federal appellate court's analysis, but they must always be present as motivating forces.

219. See supra note 6 and accompanying text.

220. See supra notes 184-87 and accompanying text.

221. See supra notes 9-16 and accompanying text.

222. See supra notes 3-8 and accompanying text. 